\title{
Baikal Region (Russia) Development Prospects Based on the Green Economy Principles
}

\author{
Alexey Bilgaev ${ }^{1,2}$, Suocheng Dong ${ }^{1, *}$, Fujia Li ${ }^{1, *}$, Hao Cheng ${ }^{1}$, Arnold Tulohonov ${ }^{3}$, Erzhena Sadykova ${ }^{3}$ and \\ Anna Mikheeva ${ }^{3}$ \\ 1 Institute of Geographic Sciences and Natural Resources Research, Chinese Academy of Sciences, \\ Beijing 100101, China; bilgaev@igsnrr.ac.cn (A.B.); chenghao@igsnrr.ac.cn (H.C.) \\ 2 College of Resource and Environment, University of Chinese Academy of Sciences, Beijing 100049, China \\ 3 Baikal Institute of Nature Management, Siberian Branch of the Russian Academy of Sciences, \\ 670047 Ulan-Ude, Russia; aktulohonov@binm.ru (A.T.); ersadykova@binm.ru (E.S.); \\ asmiheeva@binm.ru (A.M.) \\ * Correspondence: dongsc@igsnrr.ac.cn (S.D.); lifj@igsnrr.ac.cn (F.L.); \\ Tel.: +86-10-6488-9430 (S.D.); +86-10-6488-9842 (F.L.)
}

Citation: Bilgaev, A.; Dong, S.; Li, F.; Cheng, H.; Tulohonov, A.; Sadykova, E.; Mikheeva, A. Baikal Region (Russia) Development Prospects Based on the Green Economy Principles. Sustainability 2021, 13, 157. https://doi.org/10.3390/su13010157

Received: 25 November 2020 Accepted: 23 December 2020 Published: 25 December 2020

Publisher's Note: MDPI stays neutral with regard to jurisdictional claims in published maps and institutional affiliations.

Copyright: () 2020 by the authors. Licensee MDPI, Basel, Switzerland. This article is an open access article distributed under the terms and conditions of the Creative Commons Attribution (CC BY) license (https: / / creativecommons.org/ licenses/by/4.0/).

\begin{abstract}
The problems of preserving the natural environment are relevant for unique natural complexes of territories, such as the Baikal region (Russia). There are few studies devoted to forecasting the green economic development of the eco-socio-economic system of the Baikal region. The previous studies are mainly dedicated to the theory of forming the green economy in the Baikal region. This study aimed to forecast and determine future trends in the Baikal region's eco-socio-economic development based on the green economy. The methodological approach to assess the Baikal region development prospects is based on determining the factors affecting the relationship between various eco-socio-economic components using multiple regression models. We constructed the forecast using the artificial neural networks method, and we assessed the possible impact of anthropogenic factors on the Baikal region's eco-socio-economic system in the future. Based on the obtained forecast, we proposed a mechanism for regulating the green economy formation in the region. The regional governments of the Baikal region should perform the management function. This requires establishing a special interregional Green Development Fund to restructure incoming public funds by redistributing financial flows from contaminating brown to green industries and develop a state program for the Green Development of the Baikal region. The constructed forecast is informational support for decision making for the long-term development of the economy during the transition to the green economy, the development and justification of program activities, and the future's main strategic priorities.
\end{abstract}

Keywords: Russia; Baikal region; Lake Baikal; green economy; forecasting; regional Green Development Fund

\section{Introduction}

The industrial revolution, rapid industrialization, and the transition to an industrial society marked the beginning of an increase in anthropogenic emissions. Economic development based on using natural resources and traditional linear production starts from obtaining resources from nature and ends with producing products for human and discharging waste back to nature. The production mode determines the degree of human dependence on resources and impact on the environment [1]. The current coincidence of political and economic circumstances has created a new policy landscape of opportunity for alternative development strategies [2]. The slowdown of economic growth has consequences for the well-being of the population in regions with fragile nature and special regimes of natural management with established restrictions on certain economic activities. This situation leads to a conflict of interest between economic growth and environmental protection, as much of economic growth is still accompanied by environmental pollution, 
especially in developing countries. In such regions, we must pursue a new socio-economic mode, and green economy principles suit them. In the lead up to Rio+20, a number of publications attempted to move beyond simple definitions of the green economy to define guiding principles (create decent work and green jobs; promote resource and energy efficiency; use integrated decision making; be low carbon and low emissions; maintain economic growth). These principles help to clarify the interpretation of the green economy concept by different international organizations and other stakeholders. They also help to guide practitioners in the application of the green economy concept and address perceived risks and concerns [3]. The "green economy" term was framed by Pearce et al. during the late 1980s [4], relying on the idea of sustainable development and eco-socio-economic development problems concerns [5]. The green economy concept has gained popularity in international, regional, and national policy circles, initially as a response to the financial crisis [6] and a motor for growth and development [7]. The green economy is the most inclusive concept; it envelops an umbrella perspective for a balanced social-environmental development with a global research area, including ideas from both the circular economy and the bio-economy [8]. The United Nations Environment Program (UNEP) defines the green economy as one that results in "improved human well-being and social equity, while significantly reducing environmental risks and ecological scarcities" (UNEP, 2011:16); that is, an economy that is "low carbon, resource efficient, and socially inclusive" (2011:16) [9] it mainstreamed after the 2012 UN Conference on Sustainable Development in Rio de Janeiro (Rio+20) [10]. In 2012, all UN member states supported the strategy for the future of humanity, based on the transition to a "green" economy [11]. The 2015 conference adopted the UN Sustainable Development Goals (SDG) for all countries until 2030 [12]. In December 2015, UN members approved the Paris Agreement on combating climate change, noting the need to form a low-carbon economy (one of the "green economy" forms) globally [13]. Green economy envisages future economies and societies as different from current forms (e.g., energy will come from renewable sources, vehicles will use different fuels, new sectors and types of jobs will be created), but the basis of our capitalist, consumption-led economies will remain much the same [14]. At the same time, each region chooses its strategy for achieving a green economy, anyhow that both promotes and depends upon economic growth [15]. Recent macro-"experiments" in new ways of bringing about eco-social transition at a state level include Green Economy (e.g., Korea), Ecological Civilisation (China), Sufficient Economy (Thailand), and Living Well (e.g., Bolivia). All claim to address environmental, social and economic crises simultaneously, yet are diverse in terms of emphases, priorities, and implementation methods [16]. Today, five key sectors are considered part of the burgeoning North American green economy: energy from renewable resources; energy efficiency; pollution abatement and materials recycling; natural resources conservation and ecological restoration; and environmental compliance, education, training, and public awareness [17]. Effective policy integration remains central to sustainable green development and essential to pursue SDGs [12], which requires diverse expertise in different institutions and sectors [18]. German experience constitutes a test case for the strong green growth assertion, which upholds that the creation of competitive advantages in green technologies is one way to create both short- and long-term economic benefits, such as jobs [19].

In recent years, the progress of the transition to a green economy in the Baikal regionthe Republic of Buryatia, Irkutsk oblast, Zabaykalsky krai has been quite promising. Buryatia is a key subject in the Baikal region in terms of preserving Lake Baikal-73\% of the protected area is located on its territory. In November 2017, the Republic of Buryatia's first solar power plant (10 MW) was commissioned. It is planned to build four more $15 \mathrm{MW}$ plants in the centralized power supply zone in 2018 and another $30 \mathrm{MW}$ plant in 2021. In total, in the Republic of Buryatia, it is planned to build solar power plants for general use with a total capacity of $150 \mathrm{MW}$, including $2.5 \mathrm{MW}$ autonomous hybrid power plants [20]. Such changes can boost the region's economy by generating job growth and benefit in reducing $\mathrm{CO}_{2}$ emissions or an increase in energy security [21]. However, it remains unclear 
how the economic system will behave with a green economy's implemented principles. A meaningful discussion has arisen about whether the goal of green economy and green growth is relevant for low- and middle-income countries due to concerns about problems facing those countries realizing green economic development, including the large informal economy, high poverty rates and inequality, weak capacity and resources for innovation and investment, and inadequate governance and institutions [22]. There are only a few studies focused on a forecast of the socio-economic system of the Baikal region. Most of the existing research mainly focuses on analyzing the current situation, not future development [23-25].

This study aims to forecast and determine the future trends of the eco-socio-economic development of the Baikal region and assess opportunities for the transition to a green type of development. The research was carried out in the Baikal region [26] — the Baikal natural territory with an established special regime of nature management (Federal Law "On the Protection of Lake Baikal" dated 01.05.1999 N 94-FZ). The Baikal natural territory within Russia covers three regions: the Republic of Buryatia (73\%), Zabaykalsky Krai $(21 \%)$, and Irkutsk Oblast (6\%). We constructed a forecast of the Baikal region's eco-socioeconomic system development. The region's eco-socio-economic system characterizes by the fact that it has a certain potential and uses the available opportunities for dynamic development. We choose neural network models as a forecasting method $[27,28]$ because it is good at solving problems where statistical methods work poorly. It predicted future trends in the development of the region's system and gave recommendations for policy changes and proposed regulatory mechanisms to promote the introduction and use of the green economy principles. The forecast for the development of the eco-socio-economic system of the region will allow a better understanding of the future situation and make it possible to take appropriate action. This work can be useful in the study of regions similar to the region studied in this article.

\section{Materials and Methods}

\subsection{Study Area}

Lake Baikal's basin, due to geographical, geopolitical location, natural resources, economic, ethnocultural (Buddhism center of Russia) potential, and direct proximity to Lake Baikal, is the central strategic region in eastern Russia and northern Mongolia, two countries where socio-economic development is the most important pillar (Figure 1). There is a special nature management regime in the Baikal Basin (Federal law of Russian Federation 1st of May, 1999 N 94-FZ on "Protection of Lake Baikal"), which pays special attention to environment protection and dictates a ban on many types of economic activity in order to avoid environmental changes. Lake Baikal's problems attract the international community (Lake Baikal and its environs are World Heritage Site), underlining the role of great lakes as a unique natural phenomenon and as a place for organizing recreation areas of global significance, source of environmentally friendly land use and business. The uniqueness of the Baikal region is determined by the wealth of natural resources, convenient border, and transit location [29] in the center of the Asian part of Russia, as well as the ethnocultural characteristics of the peoples living in the territory where the Buddhism center of Russia is located. Under these conditions, the contradictions between the Baikal region's economic development and the problem of preserving the purity of Baikal are growing. Therefore, environmental protection becomes the essential requirement for developing any production in achieving sustainable development based on the principles of the "green economy," efficient use, and reproduction of natural resources in the Baikal region where industrial production is a leading industry, and the presence of Lake Baikal determines promising future areas of economic activity. 


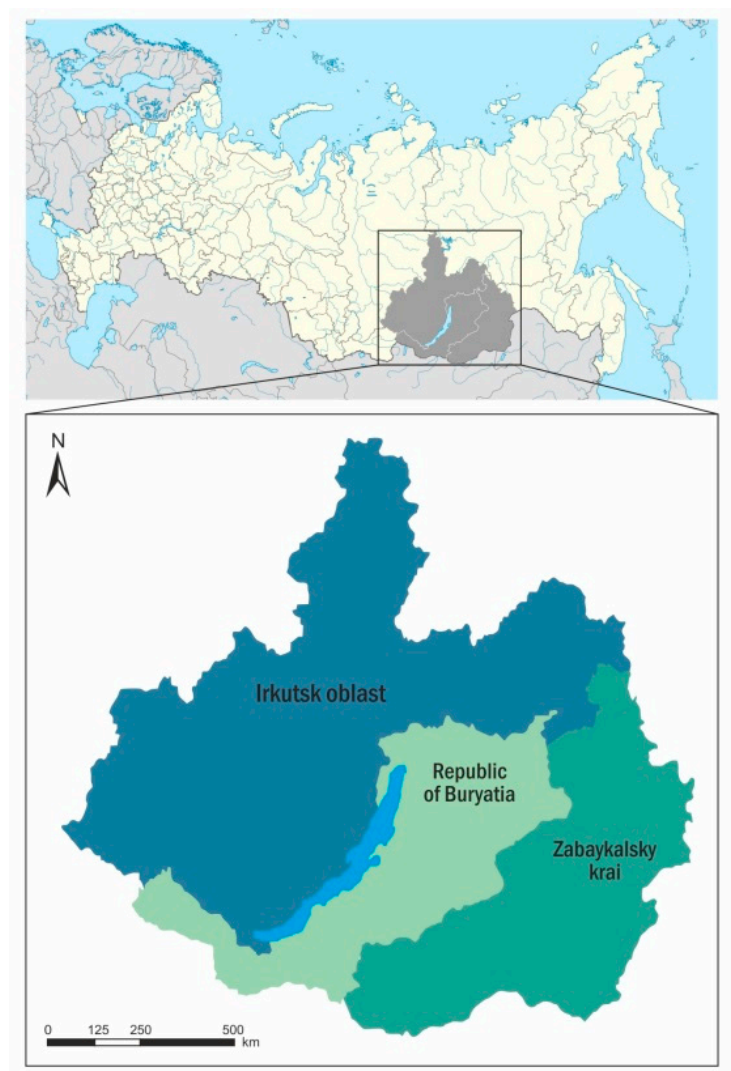

Figure 1. Baikal region.

To protect the unique ecological system of Lake Baikal, a special regime of economic and other activities carried out by the principles of priority actions that do not violate the ecosystem of Lake Baikal and its natural landscape protection zones, taking into account the complexity of the economic activity impact on Lake Baikal ecosystem; sustainabledevelopment-based solutions of socio-economic and Lake Baikal protection tasks; and mandatory state environmental expertise. Thus, the established special regime of economic and other activities imposes on the Republic of Buryatia the most significant responsibility and burden for Lake Baikal's purity.

\subsection{Statistical Method}

The algorithm of the calculations performed determines the following sequence of stages in developing a forecast of the Baikal region's eco-socio-economic development:

1. Selection of target indicators to determine the factors influencing the region's eco-socio-economic development, based on the earlier analysis [26];

2. Choosing a type of multiple regression model to identify factors;

3. Definition of linear multiple regression models;

4. Entering factors from the database into STATISTICA 8.0;

5. Result: the factors that had the greatest impact on the ecological-socio-economic development of the region;

6. Selection of a forecasting method;

7. Model of an artificial neural network with automatic topology construction;

8. Input of the identified factors using the developed software application [30];

9. Result: forecast of eco-socio-economic development of the Baikal region for the future to determine the future state.

In this study, we adopted target indicators that show the relationship between various components of the economy and the environment and obtain a quantitative characterization of the impact of environmental, economic, and social parameters on the socio-economic and environmental development of the Baikal region. In this paper, the main criterion for 
setting target indicators was the following. First, it should be information that can serve as a basis for improving green economic development activities. It should reflect the course of evolution over time with an assessment of the reasons explaining their dynamics. Second, we assumed that the target indicators should link to performance parameters; in this case, they become a means of management, and they can be recommended for inclusion in state strategic programs for the socio-economic development of the region in the future. The relevance of statistical data is determined based on the goal of the study. To construct a forecast by the neural network method, we needed a database for a sufficient period 1999-2018 [31-33].

The target indicators of socio-economic development included the following: Gross regional product (GRP) per capita; Investments in fixed assets, \% to GRP; Investments in fixed assets per capita; Unemployment rate, \%; Per capita income of the population. The environmental stress indicators include environmental indicators are eco-intensity of production and eco-capacity by type of pollution. To identify and assess the main factors affecting socio-economic and environmental development, we built models of multiple regression equations of the following form:

$$
\overline{\mathrm{Y}}_{1,2, \ldots, \mathrm{k}}=\mathrm{f}\left(\mathrm{x}_{1}, \mathrm{x}_{2}, \ldots, \mathrm{x}_{\mathrm{k}}\right),
$$

where $\overline{\mathrm{Y}}_{1,2, \ldots, \mathrm{k}}$-regressand; $\mathrm{x}$-regressor; $\mathrm{f}(\mathrm{x})$ —some function, according to it, the interaction of variables $Y$ and $x$ goes.

To build a multivariate relationship model, we used a linear multiple regression model

$$
\bar{Y}_{x}=a_{0}+a_{1} x_{1}+a_{2} x_{2}+a_{3} x_{3}
$$

The conducted statistical analysis of target indicators using the Statistica 8.0 software made it possible to identify the main factors influencing the dynamics of the Baikal region's eco-socio-economic state. Multiple regression equations made it possible to analyze factor signs and their selection for a specific target indicator.

In the Republic of Buryatia, four factors had the most significant impact on socioeconomic development's target indicators: eco-intensity of air, tons/USD; per capita industrial production, USD; share of the population with incomes below the subsistence level, \%; share of the employed population in the economy in the total population, \%. In Irkutsk oblast there are five factors: per capita industrial production, USD; share of the employed population in the economy in the total population, \%; industrial production indices (\% to the previous year); discharge of contaminated wastewater, $\mathrm{m}^{3}$; emissions from stationary sources, $\mathrm{kg}$; generation of production and consumption of waste, $\mathrm{kg}$. There are four factors in Zabaykalsky krai: share of the employed population in the economy in the total population, $\%$; industrial production indices ( $\%$ to the previous year); per capita industrial production, USD; generation of production and consumption of waste, $\mathrm{kg}$.

Table 1 presents the factorial features determined by the method of correlation analysis using the software Statistica 8.0. They have the greatest impact on each of the environmental indicators of the Republic of Buryatia and used for forecasting environmental indicators; Table 2 presents the factorial features for Irkutsk oblast and Zabaykalsky krai. 
Table 1. Environmental indicators and their factorial features for the Republic of Buryatia.

\begin{tabular}{|c|c|c|c|c|c|}
\hline No. & Indicator & Units & & Factors & Units \\
\hline \multirow{2}{*}{1} & \multirow{2}{*}{$\begin{array}{l}\text { Eco-capacity of air (total amount of } \\
\text { pollution per capita) }\end{array}$} & \multirow{2}{*}{$\mathrm{kg}$} & 1 & GRP per capita & USD \\
\hline & & & 2 & Per capita income & USD \\
\hline \multirow{2}{*}{2} & \multirow{2}{*}{$\begin{array}{l}\text { Eco-capacity of water resources (total } \\
\text { amount of wastewater per capita) }\end{array}$} & \multirow{2}{*}{$\mathrm{m}^{3}$} & 1 & Per capita industrial production & USD \\
\hline & & & 2 & $\begin{array}{l}\text { Share of the population with incomes } \\
\text { below the subsistence level }\end{array}$ & $\%$ \\
\hline \multirow{3}{*}{3} & \multirow{3}{*}{$\begin{array}{l}\text { Eco-capacity of waste (total amount of } \\
\text { waste per capita) }\end{array}$} & \multirow{3}{*}{$\mathrm{kg}$} & 1 & Investments in fixed assets per capita & USD \\
\hline & & & 2 & Share of the employed population in & $\%$ \\
\hline & & & 3 & Unemployment rate & $\%$ \\
\hline \multirow{3}{*}{4} & \multirow{3}{*}{ Eco-intensity of air } & \multirow{3}{*}{ tons/USD } & 1 & Per capita income & USD \\
\hline & & & 2 & Per capita industrial production & USD \\
\hline & & & 3 & Unemployment rate & $\%$ \\
\hline \multirow{2}{*}{5} & \multirow{2}{*}{ Eco-intensity of water resources } & \multirow{2}{*}{ tons/USD } & 1 & GRP per capita & USD \\
\hline & & & 2 & Per capita income & USD \\
\hline \multirow{3}{*}{6} & \multirow{3}{*}{ Eco-intensity of waste } & \multirow{3}{*}{ tons/USD } & 1 & Investments in fixed assets per capita & USD \\
\hline & & & 2 & $\begin{array}{l}\text { Share of the employed population in } \\
\text { the economy in the total population }\end{array}$ & $\%$ \\
\hline & & & 3 & Unemployment rate & $\%$ \\
\hline
\end{tabular}

Table 2. Environmental indicators and their factorial features for Irkutsk oblast and Zabaykalsky krai.

\begin{tabular}{|c|c|c|c|c|}
\hline No. & Indicator & Units & Factors & Units \\
\hline 1 & $\begin{array}{l}\text { Eco-capacity of air (total amount of } \\
\text { pollution per capita) }\end{array}$ & $\mathrm{kg}$ & $\begin{array}{c}\text { GRP per capita } \\
\text { Investments in fixed assets } \\
\text { Investments in fixed assets per capita }\end{array}$ & $\begin{array}{l}\text { USD } \\
\% \text { to GRP } \\
\text { USD }\end{array}$ \\
\hline 2 & $\begin{array}{l}\text { Eco-capacity of water resources (total } \\
\text { amount of wastewater per capita). }\end{array}$ & $\mathrm{m}^{3}$ & $\begin{array}{l}\text { Per capita industrial production } \\
\text { Share of the employed population in } \\
\text { the economy in the total population }\end{array}$ & $\begin{array}{c}\text { USD } \\
\%\end{array}$ \\
\hline 3 & $\begin{array}{l}\text { Eco-capacity of waste (total amount of } \\
\text { waste per capita) }\end{array}$ & $\mathrm{kg}$ & $\begin{array}{l}\text { Unemployment rate } \\
\text { Per capita income }\end{array}$ & $\begin{array}{c}\% \\
\text { USD }\end{array}$ \\
\hline 4 & Eco-intensity of air & tons/USD & Industrial production indices & $\%$ to the previous year \\
\hline 5 & Eco-intensity of water resources & tons/USD & & \\
\hline 6 & Eco-intensity of waste & tons/USD & & \\
\hline
\end{tabular}

\subsection{Neural Network Method}

The problem of forecasting the Baikal region's eco-socio-economic development is a priority in forming a "green economy," and it is inextricably linked with its future. The forecasting results are necessary to substantiate the goals and objectives of the further development of the Baikal region's economy and to develop and substantiate program measures in the transition to a "green economy" and sustainable development. Among the common methods used to solve the forecasting problem, statistical methods and Data Mining methods can be distinguished. Statistical methods include autoregression, regression analysis, time-series extrapolation [34,35]. Artificial neural networks, decision trees, and others can be distinguished among the Data Mining methods [36-38]. This modeling method allows the reproduction of complex dependencies. In problems where the linear approximation is unsatisfactory, statistical models perform poorly. Neural networks cope with the "curse of dimension," which does not allow modeling linear dependencies in the case of a large number of variables. The Baikal region, as a unique object of research, has its characteristics. Using a neural model made it possible to take them into account and build 
a more realistic forecast. In this study, using the Baikal region example, this method was tested and showed good results.

Therefore, to forecast the eco-socio-economic development of the Baikal region, we chose artificial neural networks with automatic topology construction, particularly the forecasting method proposed in $[27,28]$, and the software developed on its basis [30]. This forecasting technique is based on the use of a multilayer perceptron (MLP) [39] in combination with evolutionary calculations $[40,41]$. Figure 2 shows an example of the perceptron network structure.

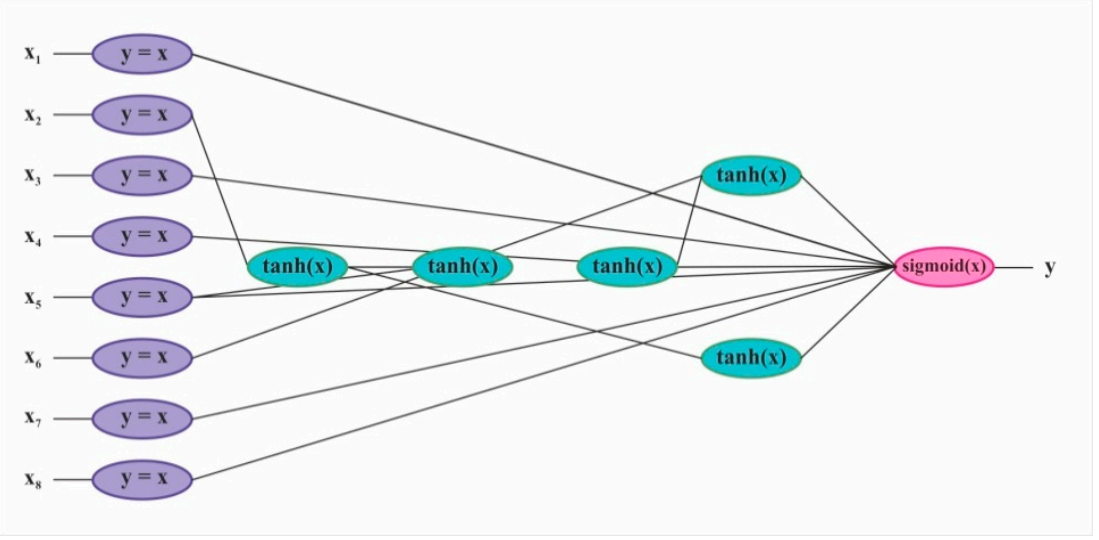

Figure 2. Perceptron network example.

A non-linear function of the sigmoidal type is used as a neuron activation function in a multilayer perceptron. It is continuous and is expressed as a unipolar or bipolar sigmoidal function $[42,43]$. The formula represents the unipolar function

$$
f(x)=\frac{1}{1+e^{-\beta x}}
$$

and bipolar function

$$
f(x)=\tanh (\beta x) .
$$

Here, the parameter $\beta$ is selected by the user and determines the slope of the sigmoidal function. When choosing a sigmoidal function, one should consider the possible output values of a neuron: a unipolar function produces a value in the range from 0 to 1 , a bipolar one-from -1 to 1 . The input layer neurons are described by the linear function ReLU of the form $f(x)=x$. This means that the input signal is passed on to other neurons unchanged.

The Formula (5) determines the neuron output signal.

$$
\mathrm{Y}=\sum \mathrm{x}_{\mathrm{i}} \cdot \mathrm{w}_{\mathrm{i}}
$$

where $\mathrm{x}_{1}, \ldots, \mathrm{x}_{\mathrm{n}}$-multiple neuron inputs; $\mathrm{w}_{1}, \ldots, \mathrm{w}_{\mathrm{n}}$-weight of the corresponding neuron input.

Then $Y$ enters the input of the activation function, determining the final signal of excitation or inhibition of the neuron at the output, that is

$$
\mathrm{OUT}=\mathrm{F}(\mathrm{Y})
$$

The choice of initial values close enough to the optimal ones significantly speeds up the learning process. Removing the starting point of neuron activation from the saturation zone is achieved by limiting the range of random values. Good results are obtained by a uniform distribution of weights, normalized for each neuron in amplitude

$$
\omega_{\text {in }}=\frac{2}{\left(\mathrm{n}_{\text {in }}\right)^{1 / 2}}
$$


where $n_{i n}$-means the number of inputs of the neuron.

In the forecasting methodology and the program $[27,28,30]$, the neural network training algorithm was used using the NEAT method, which uses a genetic algorithm and automatically builds the neural network topology in the learning process [44]. This method trains neural networks for target indicators. For training neural networks designed to predict factorial features, the window method is used [45]. Since all factorial features are independent of each other (their training and testing perform parallelly), this significantly increases neural network productivity [46].

The forecasting process using a neural network consisted of the following steps: preparation of the source data, training a neural network using a genetic algorithm, forecasting factorial features, and forecasting target environmental indicators of the eco-socio-economic development of the Baikal region. The sample of initial data was a time series from 1999 to 2018.

The information base is based on state statistics provided on the websites of the state statistics Committee of the Russian Federation and regional state statistics services [47-50] and contains ecological, socio-economic indicators of three regions: the Republic of Buryatia, Irkutsk oblast, and Zabaykalsky krai.

\section{Results}

The transition to a green economy and the sustainable development of the Baikal region inextricably linked to its environmental status in the future. Therefore, the problem arises of predicting the socio-economic development of the region, taking into account environmental factors based on the determination of environmental intensity indicators.

In the study, based on the methods of correlation analysis in Statistica 8.0, we identified the main factorial features that have the greatest impact on each of the economic indicators of the Baikal region. The results obtained on the assessment of the main factors affecting the socio-economic development of the region allowed us to build a forecast of target economic indicators. We conducted a number of experiments on long-term forecasting of the main economic indicators. Figures 3-7 show the dynamics of calculated indicators that characterize the level of socio-economic development of the Baikal region since 2018 (actual), 2019 (estimate), and forecast for 2020-2030, respectively.

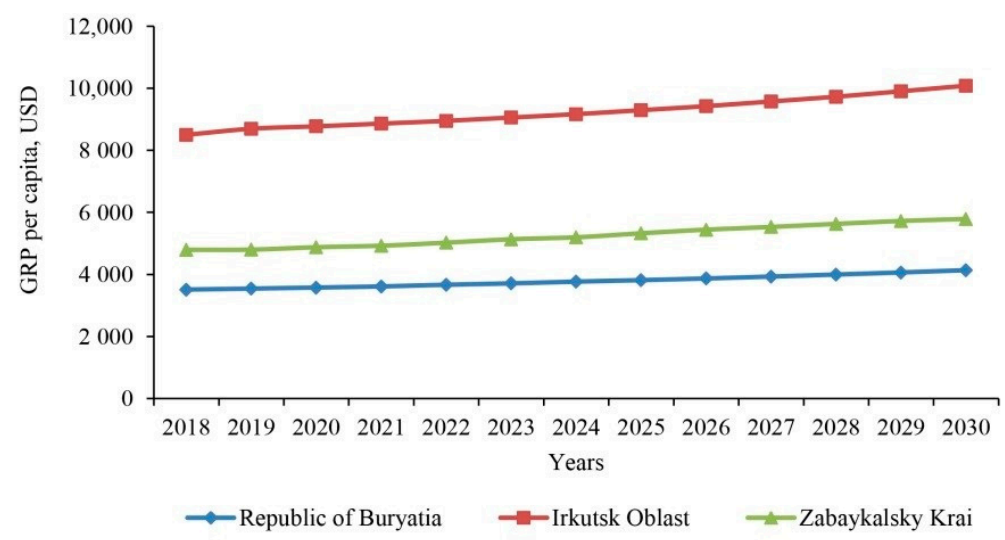

Figure 3. Forecast of GRP per capita in the Baikal region for 2019-2030. 


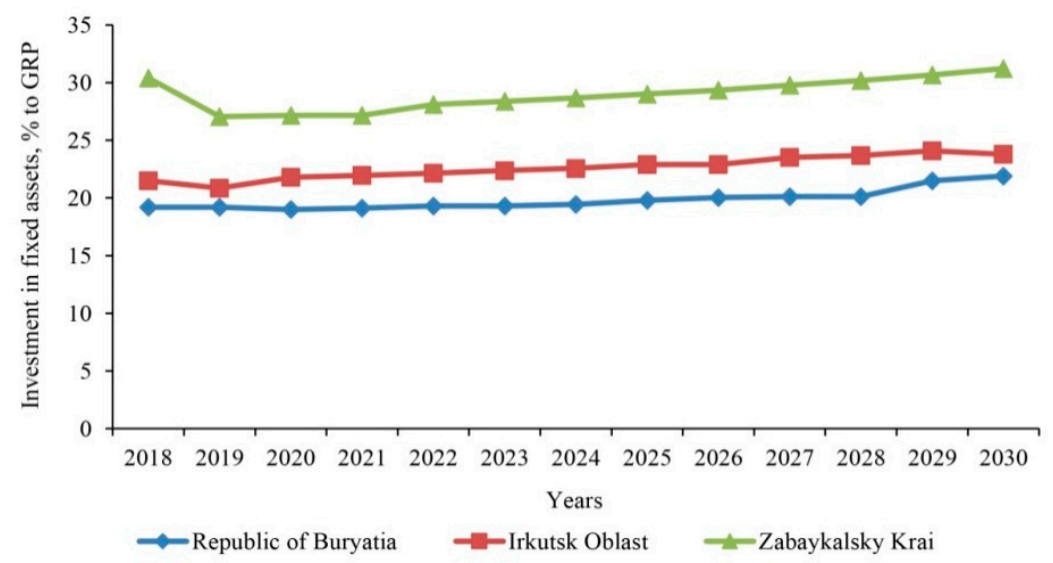

Figure 4. Forecast of investment in fixed capital in the Baikal region for 2019-2030, in \% to GRP.

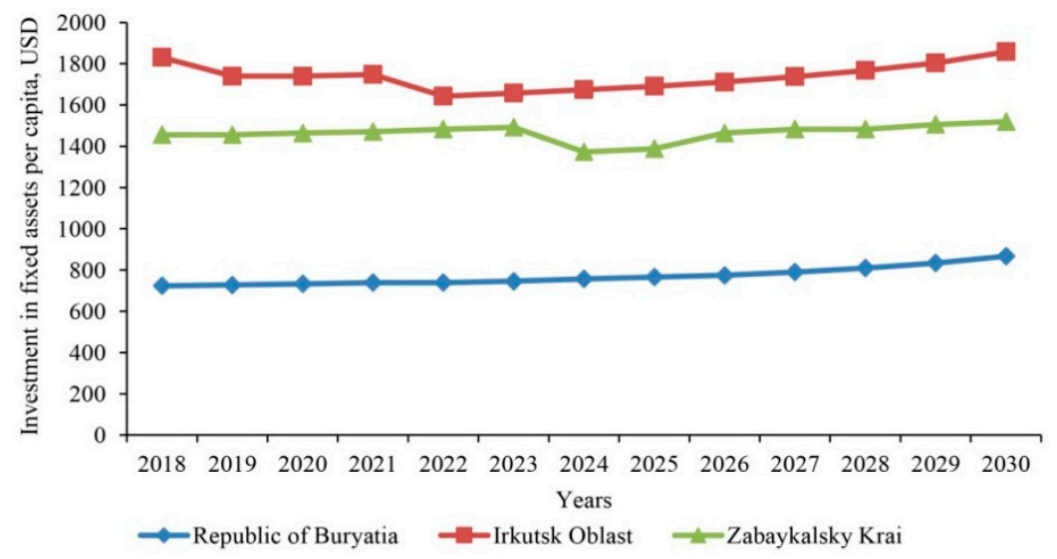

Figure 5. Forecast of investment in fixed capital per capita in the Baikal region for 2019-2030.

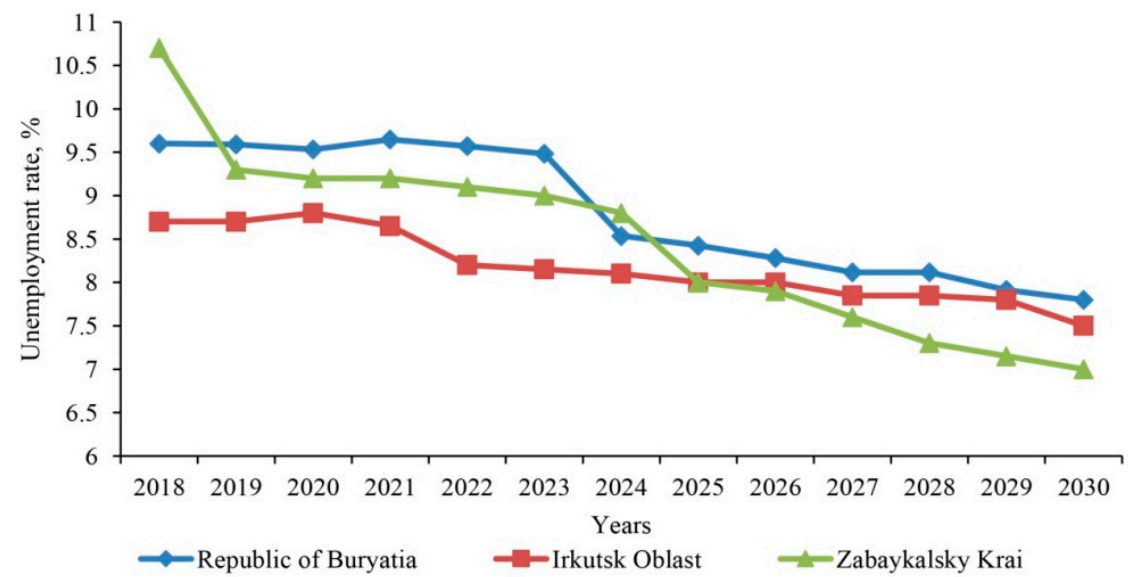

Figure 6. Forecast of the unemployment rate in the Baikal region for 2019-2030, \%. 


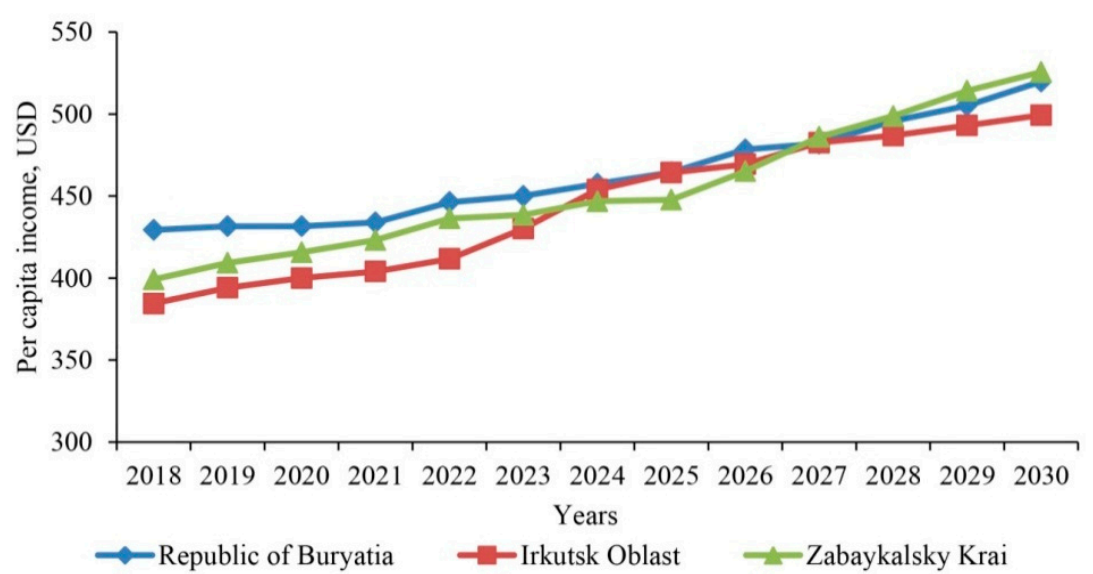

Figure 7. Forecast of average per capita income in the Baikal region for 2019-2030.

The resulting indicator of the economic activity-GRP per capita gives the overall picture of the regions' economic development. In Irkutsk oblast for the forecast period, GRP per capita growth rate will be $118.6 \%$, and in Zabaykalsky krai in 2030 compared to 2018 will be an increase by $20.72 \%$ in the Republic of Buryatia-by $17.8 \%$. The highest growth rate will be observed in Zabaykalsky krai because we expect the mining industry's accelerated development as the leading sector of the economy in the future. The dynamics of the Republic of Buryatia will be affected by the inertia of the pre-forecast period. As for investments in fixed assets (\% to GRP), the highest growth rate is expected in the Republic of Buryatia (114.6\%). This will be due to the state's increased attention to the environmental situation. In Irkutsk oblast it will be $111.7 \%$, and in Zabaykalsky krai-102.7\%. The next indicator is the forecast for investments in fixed assets per capita. The largest expected growth of this indicator in Zabaykalsky krai will indicate that the overall increase in investment in the mining industry's development will also affect the dynamics of the indicator per capita. The projected growth in 2030 to the level of 2018 will be $101.4 \%$ and $112.7 \%$ in Irkutsk oblast and Zabaykalsky krai, respectively, and $108.5 \%$ in the Republic of Buryatia.

In Irkutsk oblast over the forecast period, the growth rate of GRP per capita will be $118.6 \%$, and in Zabaykalsky krai, an increase of $20.72 \%$ will occur in 2030 compared to 2018. In terms of investment in fixed capital (as a percentage of GRP), the growth rate in the Irkutsk oblast will be $111.7 \%$ and $102.7 \%$ in Zabaykalsky krai, respectively. Forecast results for investment in fixed assets per capita in Irkutsk oblast and Zabaykalsky krai are $101.4 \%$ and $112.7 \%$.

The key component of the region's functioning and development is the human factor, which acts as a leading subject and object of ongoing changes in the formation of a green economy. In this regard, the study of the labor potential and measurement of the population's quality of life will allow fully assess and determine further actions for the eco-socio-economic development of the Baikal region in the future. The results showed that the decrease in unemployment in the Republic of Buryatia over the forecast period will be $81.3 \%$ or $18.7 \%$; $86.2 \%$ or $13.8 \%$ in Irkutsk oblast; and in Zabaykalsky krai, the largest decrease is $65.4 \%$.

The forecast for indicator average per capita income showed growth by $21.1 \%$ in the Republic of Buryatia; Irkutsk oblast and Zabaykalsky Krai, respectively, it was $29.9 \%$ and $31.6 \%$.

The most important indicators that characterize the change in the environmental situation in the regions are the environmental intensity indicators. They reflect the overall level and degree of anthropogenic impact on the environment. These include indicators of eco-intensity or intensity of pollution and eco-capacity, which, in our opinion, show the impact strength on the environment due to economic activity on nature and humans. 
The obtained results of the eco-capacity indicators forecast of the Baikal region are presented in Table A1 in Appendix A. Figures 8-10 show the dynamics of the calculated indicators characterizing the level of environmental pollution: eco-capacity of air, wastewater, and waste for 2018 and forecast for 2019-2030.

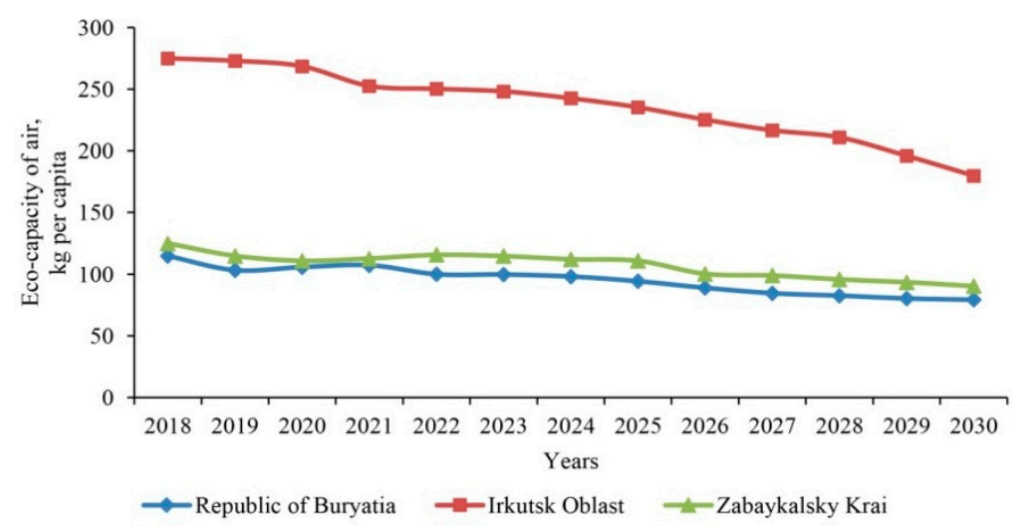

Figure 8. Forecast of the eco-capacity of air in the Baikal region for 2019-2030.

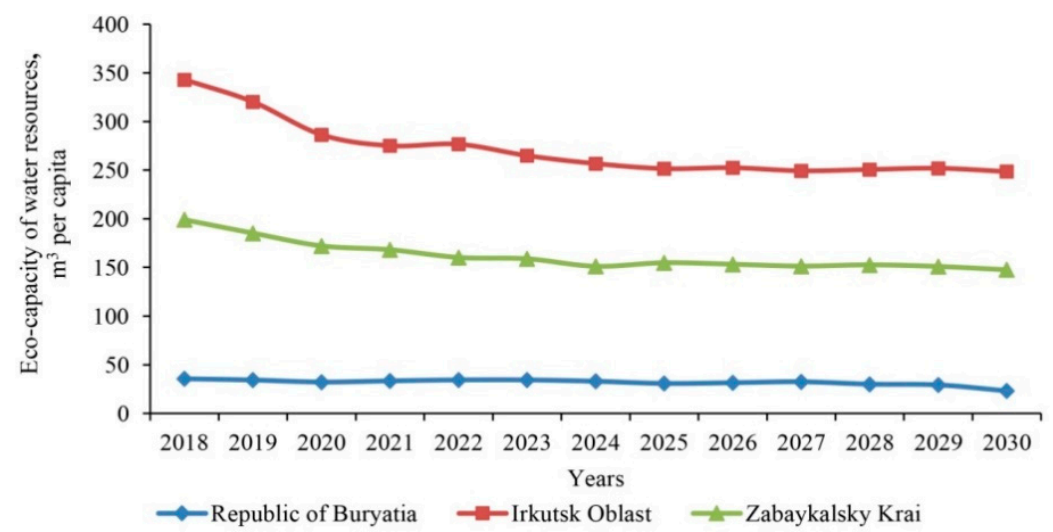

Figure 9. Forecast of the eco-capacity of wastewater in the Baikal region for 2019-2030.

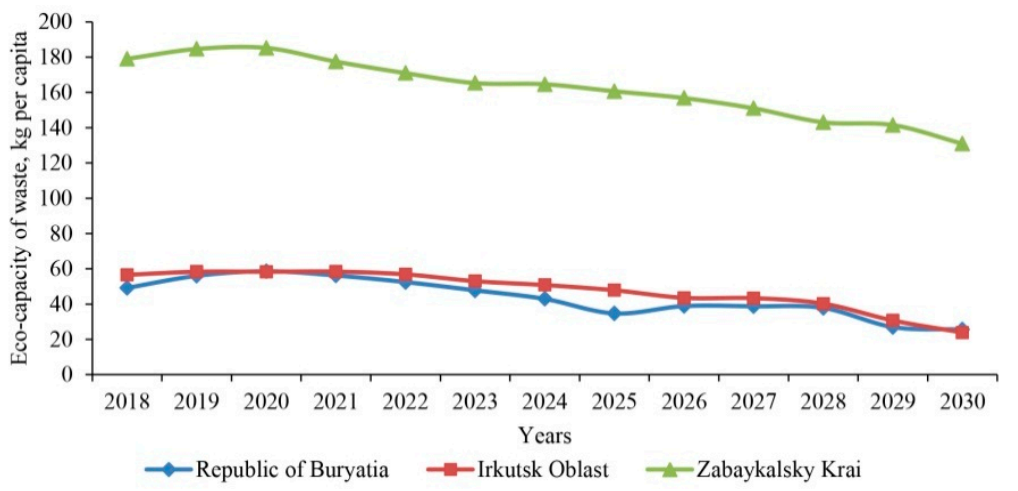

Figure 10. Forecast of the eco-capacity of waste in the Baikal region for 2019-2030.

For the eco-capacity of air indicator in the Republic of Buryatia, the decrease will be $35.51 \mathrm{~kg} /$ person (or by 30.9\%), to the level of 2018; in Irkutsk oblast, it will be $95.2 \mathrm{~kg} / \mathrm{person}$ (34.6\%); in Zabaykalsky krai, a decrease of $34.7 \mathrm{~kg} /$ person will occur in 2030 compared to $2018(34.7 \%)$. The dirtiest region by air is Irkutsk oblast, since a cascade of thermal and hydroelectric power plants is located in its territory. The expected decrease in environmental friendliness of the air shows a positive trend. According to the eco-capacity of wastewater, the largest decline will occur in Buryatia, the rate of fall $65 \%$ in Irkutsk oblast and Zabaykalsky Krai is $72.5 \%$ and $74.2 \%$. In recent years, preceding the forecast 
period, the most radical wastewater treatment measures were observed in the Republic of Buryatia. Most of the waste is generated by mining precious metal ores, rare metal ores, coal mining, and building materials production. Following the results obtained, the eco-capacity of waste in the Republic of Buryatia and Irkutsk oblast will decrease by two or more times- $48 \%$ and $57.8 \%$, respectively. In Zabaykalsky krai, it will decrease by a quarter $(26.89 \%)$, since the mining industry has developed rapidly in recent years, waste disposal and disposal are the most acute in the region.

The results obtained in the construction of the forecast of the indicators of the ecointensity of the Baikal region (Table A2) are influenced by the general dynamics of the GRP growth and the dynamics of the increase of air, water, and waste pollution. Figures 11-13 show the dynamics of the calculated indicators characterizing the level of environmental pollution: the eco-intensity of air, wastewater, and waste for the analyzed past period for 2018 and forecast for 2019-2030.

The forecast results for the indicators of eco-intensity of air showed that this indicator will decrease in all studied federation subjects-in Buryatia by $20 \%$, in Irkutsk oblast by $16.4 \%$, and in Zabaykalsky krai by $13.46 \%$. In terms of eco-intensity of wastewater, Buryatia showed a decrease of $80.9 \%$, Irkutsk oblast $69.9 \%$, Zabaykalsky krai $41.1 \%$. Eco-intensity of waste in these subjects of the federation will decrease by $75.6 \%$ (Republic of Buryatia), $40 \%$ (Irkutsk oblast), and 35\% (Zabaykalsky krai).

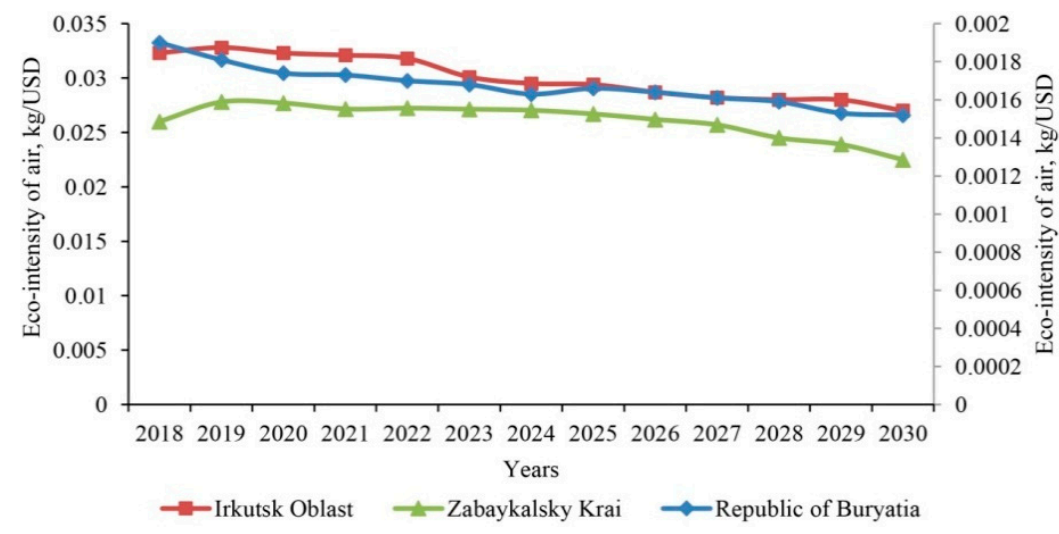

Figure 11. Forecast of the eco-intensity of air in the Baikal region for 2019-2030.

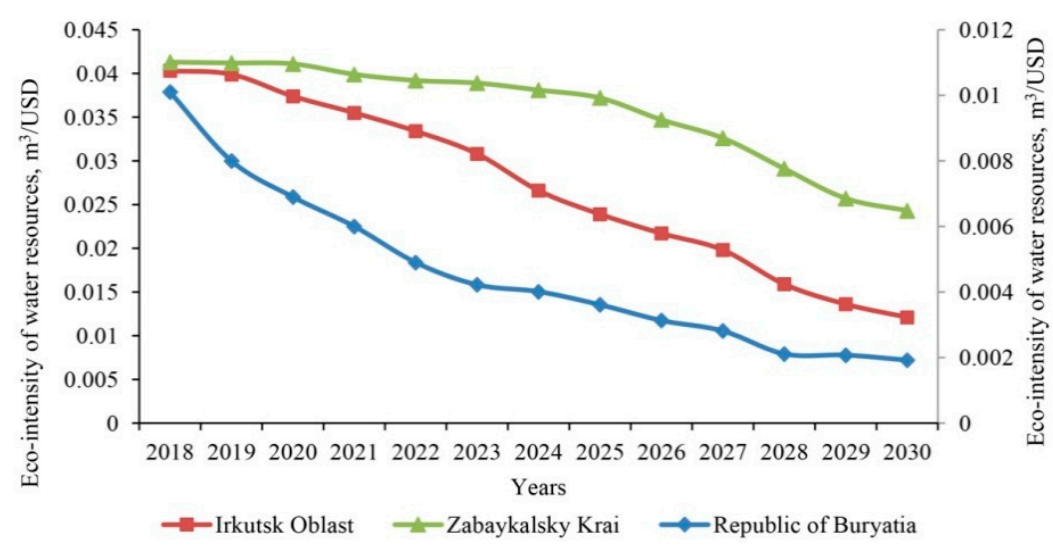

Figure 12. Forecast of the eco-intensity of wastewater in the Baikal region for 2019-2030. 


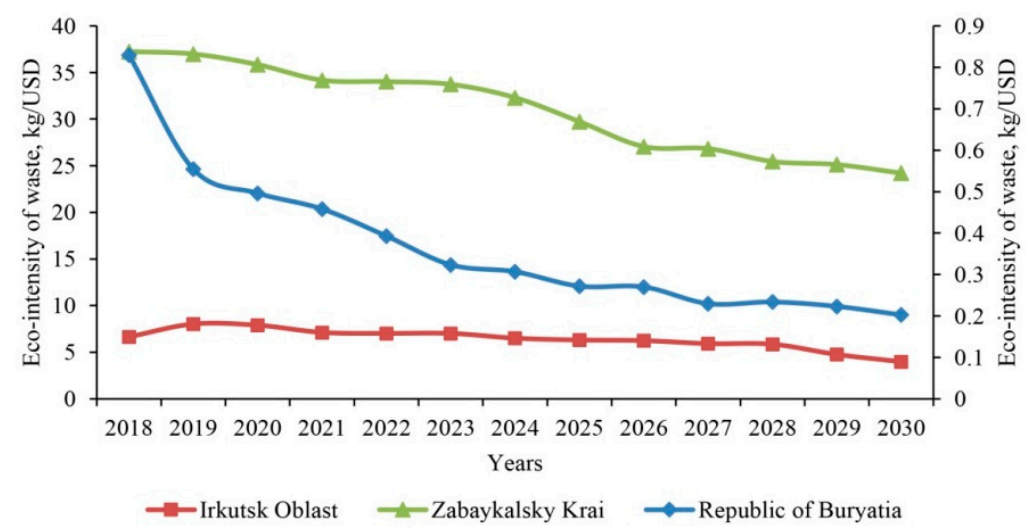

Figure 13. Forecast of the eco-intensity of waste in the Baikal region for 2019-2030.

\section{Discussion}

1. The results of the forecast of the main socio-economic indicators of the Baikal region showed the following. We found that in the Republic of Buryatia, which bears the greatest environmental burden, by 2030, the positive dynamics of the main indicators is expected. GRP per capita (an increase of $117.8 \%$ to the level of 2018); the increase in investment activity, which is indicated by the share of investment in fixed assets (\% to GRP), the growth rate for 2018-2030 will be 114.1\%; investment in fixed assets per capita will be $108.5 \%$. The labor trend in the Baikal region will have a positive direction. Due to a slight increase in the population, which will be the result of natural population growth and the stabilization of the migration movement through measures aimed at reducing overall unemployment, especially in rural municipalities and the development of all forms of small business, there will be a general decrease in the unemployment rate. The main factors that influenced the change in the unemployment rate were, first, a slight increase in the share of the employed population in the total population due to the general processes of population aging [26]; and second, the projected increase in the share of employees employed in small enterprises $[51,52]$. One of the main indicators that characterize the social development and quality of life is the average per capita income of the population. The forecast results of this indicator showed that the implementation of the strategic directions to improve quality of life of the population of the Baikal region will reduce the financial and property stratification of citizens of the Republic. Simultaneously, the level of per capita incomes sufficient to use the best quality services will increase.

A positive factor can be considered that the forecast of the eco-capacity of waste in the Baikal region will tend to decrease due to ongoing measures for the disposal and neutralization of production and consumption waste. This indicator's dynamics will become unstable due to several objective reasons, including increasing the discharge of pollutants and increasing industrial production rate. As a result of the obtained forecast of eco-capacity of air in the Baikal region by 2030, the decrease is expected.

Based on the forecast results for the eco-intensity of air in the Baikal region, we can say that, by 2030, positive dynamics is expected in the Republic of Buryatia, and the eco-intensity of air will decrease. In Irkutsk oblast and Zabaykalsky krai, against the background of the general forecast decline in this indicator, a slight increase will be observed over several years. The main reason is that, in some past years preceding the forecast period, there was a fairly significant increase in air emissions of pollutants both in the Irkutsk oblast and Zabaykalsky krai, which affected the results obtained. The predicted values of the indicator of the eco-intensity of wastewater in the Baikal region can be estimated from a positive point of view since its decrease will be observed throughout the region. As the results of the forecast of the eco-waste intensity indicator in the Baikal region show, it will decrease in the Republic of Buryatia and Irkutsk oblast. In Zabaykalsky krai, there will be a slight increase in the dynamics of the eco-waste intensity indicator affected by previous years' inertia, so the future dynamics is unstable. 
Achieving an optimal level of reproduction of material goods and services is possible by using competitive advantages associated with the fact that the Baikal region is an object of a model territory that meets the main imperatives of sustainable development. This requires business development conditions, state support for investment projects, activation of institutional transformation processes, overcoming poverty, and creating attractive living conditions.

The necessary condition for implementing forecast results is the positive orientation of political and economic stability. Given that Lake Baikal is a "global environmental strategic resource," the significance of which goes beyond the national framework. Russia and the world community should be objectively interested in the green economic development of the Baikal region. Implementation of the strategic directions for the transition economies on a green path of development is possible through a continuous process of development and innovation, optimum use of the resource, and the scientific and educational potential of the region, in order to achieve a higher degree of innovativeness and sustainability industries in the Baikal region on the levels of adaptability. The study results allowed us to establish that the achievement of the goals set in the balanced economic development and the sustainability of the Baikal region's eco-socio-economic development in the transition to a green economy is possible with the state regulation of socio-economic processes [53].

2. We propose the mechanism for regulating the Baikal region's sustainable development based on the green economy principles and approach to transition to the green economy described in [17,54] (Figure 14), including eco-capacity indicators into the system of target indicators of state programs. From our point of view, the economy of the Baikal region can implement a model project for the transition from development with a raw material orientation to an innovative path (which is actively declared at the macro level) [55], in which the incomes of competing regions will depend on organizational and technological innovations. Within the framework of a single state, in neighboring regions with economically imbalanced systems, for the growth of ecological and economic development, there is an obvious need for the formation of integration processes for smoothing and effective interaction in the development of a macro-region, based on the principles of a green economy. For this, we propose that the integrated regional governments of the Baikal region launch the state program of the Green development of the Baikal region that, first of all, should determine the forms and methods of state support; determine the list of those eligible for subsidies and subsidies; establish the procedure for granting subsidies and reporting; introduce preferential taxation for new green investment projects; and create special territories for socio-economic development with special conditions for the organization of green non-resource production that is export-oriented. Moreover, we propose to establish a special interregional fund for the Green Development of the Baikal Region.

This mechanism's main idea is the restructuring of the incoming public funds; the essence is to redistribute the financial flows from the pollution of brown industries to green ones. When implementing the mechanism of interregional environmental and economic activity, it is necessary to take into account the interests of business owners-it is required to create a number of regulatory legal acts that allow minimizing the potential decline in the profitability of energy and other businesses, which arose through territorial preferences, in other words, with the help of landscaping opportunities. Green entrepreneurs are essential to this process of making and remaking, in that their narratives help to expand the concept of the green economy and to make present alternatives that challenge the current obsession with economic growth and continued expansion of consumption [56]. To provide the enterprise with subsidies for introducing green technologies and technologies, use grants for green development, partially reimburse the costs of re-equipment and introduce green technologies into production facilities; subsidized rates, credits, and tax credits. It is also necessary to provide the enterprises with personnel-the organization of training courses and retraining courses. Furthermore, eco-socio-economic processes forecast must involve scientific institutes, allowing us to quickly and accurately understand 
the current situation and work out development strategies for each enterprise, which will attract private companies to participate in green projects.

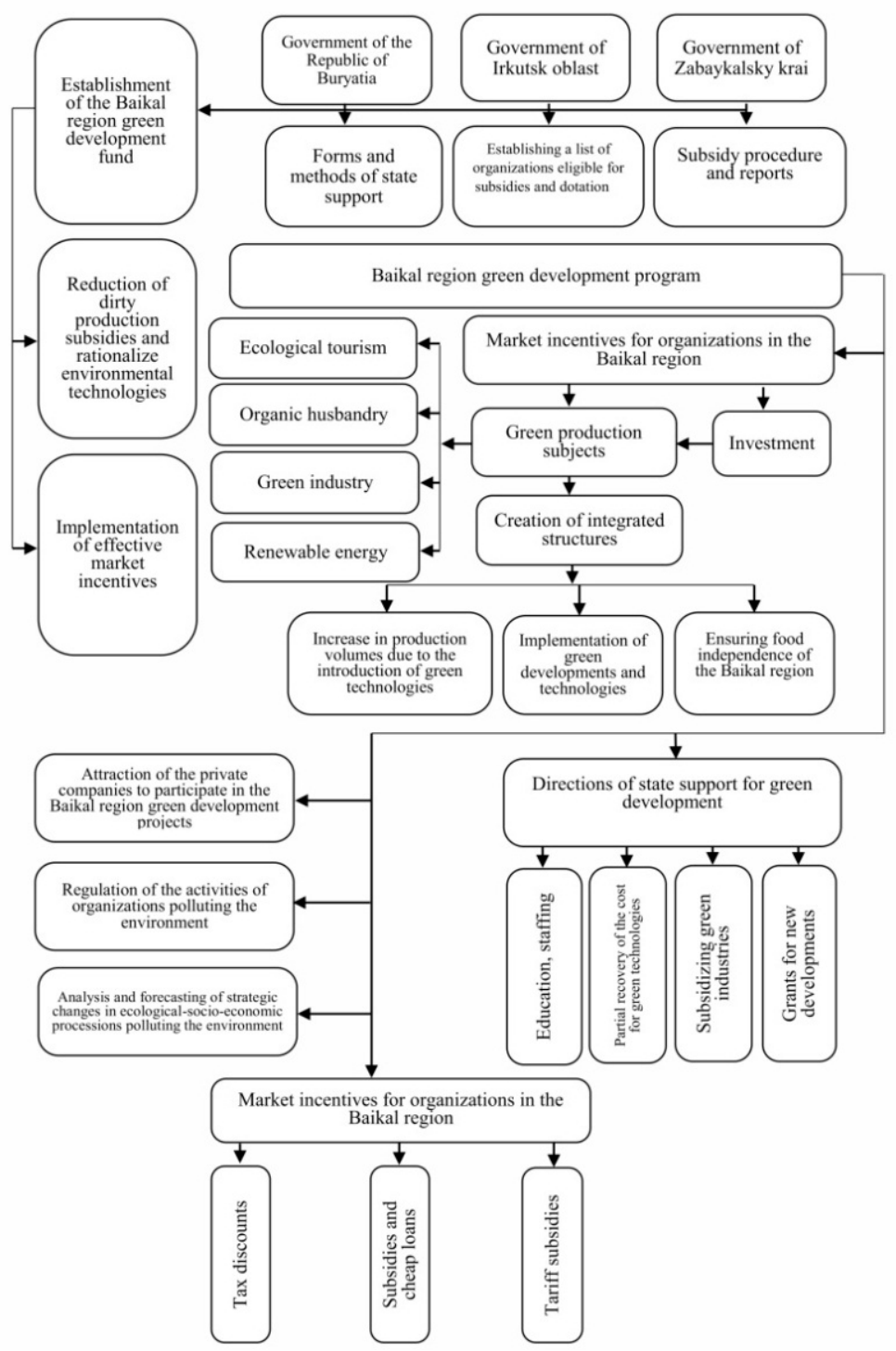

Figure 14. Mechanism for regulating the Baikal region's sustainable development based on the green economy principles.

3. One of the most important components of the Baikal region's socio-economic development is the introduction of innovations that will eliminate the damage of the past years and ensure the possibility of positive interaction between humans and nature. For example, renewable energy, insolation is exceptionally high in the Baikal region, which suits developing utility-scale solar energy (USSE) infrastructure [57,58]; in some areas almost always blowing winds, wind power has been one of the fastest growing energy generation technologies over the last two decades. In 2014, installed wind energy capacity amounted to $370 \mathrm{GW}$, with China, the US, and Germany being the world leaders [59]; or use of waste in activities like agriculture (biomass) [60]. Now it is necessary to carry out an extensive modernization of energy facilities, gradually abandoning traditional dirty energy sources in favor of increasing energy production using alternative sources. As technology improves and the scale of production of solar cells increases, their price gradually decreases. It allows us to speak about a significant drop in the cost of "solar electricity," which allows alternative energy sources to compete with traditional production. Even if the renewable deployment is inspired by economic, rather than environmental (green), considerations it can indeed 
create at least short-term socio-economic benefits and thus supports the main assertion of strong green growth [18]. For this, it is necessary to create conditions for attracting investments from the state and private business. Active actions in the field of energy-saving will reduce environmental pollution. One option is to take advantage of the experience of China, wherein 2017 alone investments in renewable energy amounted to 126.6 billion dollars, which is 23 billion more than all developed countries combined. Optimization of industrial structure, governmental pollution abatement expense, and environmental policy have a significant and positive effect on environmental quality [61].

4. To achieve sustainable green economic development, overcome negative tendencies in the national economy sectors that harm the environment, employment, living conditions, and reduce the outflow of population from rural areas-to increase the rate of development of the eco-socio-economic system of the Baikal region, we should take the following actions:

- Introduce more functional treatment facilities, waste sorting stations, water-saving systems, and improve water use's economic mechanism. Reconstruction and modernization of industrial production, work on the creation and use of environmentally friendly technologies. To make higher demands on the location and functioning of the productive forces in the region;

- Develop a feasibility study for the creation of environmentally friendly production in the mining industry and the fuel and energy sector;

- Create and modernize transport and energy infrastructure that can create new green jobs [62];

- Exercise control over the observance of existing laws on environmental protection and ensure the environmental safety of the population and the preservation of natural systems. to study the negative impact of emissions and discharges of harmful (polluting) substances on the natural territory of Lake Baikal and develop scientifically based recommendations for their regulation; full coverage of the state environmental monitoring of the Baikal natural territory;

- Develop ecological tourism, which is more suitable for Baikal's status as a world natural monument. Such tourism, firstly, does not violate the integrity of the ecosystem, and secondly, it is beneficial to the local population. Ecological tourism is inherently expensive tourism, and it cannot be massive. The very massive nature of the tourist flow negates the possibility of full-fledged communication between man and nature, which should be the meaning of rest on Lake Baikal [63]

The scale of the climate, biodiversity, and inequality challenge is so urgent and so huge that leadership from all sectors is to be welcomed, and a radical collaboration between them is critical. The COVID-19 pandemic will have massive implications for the global economy and financial markets. It is necessary to take this factor into account in further research [64].

\section{Conclusions}

As a result of the study, the obtained forecast of the Baikal region's eco-socio-economic development made it possible to assess the possibilities of the formation of a green economy and to build its regulation mechanism. The proposed regulation mechanism, with the inclusion of eco-potential indicators in the target indicators of state programs, is based on the integration of regional governments of the federation subjects that are part of the Baikal region. Creating a special interregional Green Development Fund, and working to restructure the incoming public funds, will provide financial resources for the implementation of investment projects and stimulate organizations involved in developing and implementing environmental technologies.

In the future, it is necessary to improve the proposed approaches to study regional eco-economic trends, considering directions for the development of the "green economy" and the emergence of various risks. This forecast can provide real information support in solving the problems of further development of the Baikal region's economy on the way to green development. 
Author Contributions: Conceptualization, A.B., S.D. and E.S.; methodology, E.S.; software, A.B.; validation, S.D. and F.L.; formal analysis, A.B.; investigation, A.B. and E.S.; resources, S.D. and H.C.; data curation, A.B. and H.C.; writing-original draft preparation, A.B.; writing-review and editing, S.D. and F.L.; visualization, A.M.; supervision, S.D., F.L. and A.T.; project administration, S.D.; funding acquisition, S.D., F.L. and H.C. All authors have read and agreed to the published version of the manuscript.

Funding: This research was funded by Class A strategic leading science and technology project of Chinese Academy of Sciences (Grant number XDA20030203), Science \& Technology Basic Resources Investigation Program of China (Grant number 2017FY101304), National Natural Science Foundation of China (Grant number 42071282, 41911530103 and 41701639), Russian Foundation for Basic Research (Grant number 19-55-53026), State assignment of BINM SB RAS (Grant number 339-2019-0002), National Natural Science Foundation of China (Grant number 71733003).

Institutional Review Board Statement: Not applicable.

Informed Consent Statement: Not applicable.

Data Availability Statement: No new data were created or analyzed in this study. Data sharing is not applicable to this article.

Acknowledgments: The first author would like to acknowledge Chinese Academy of Sciences-The World Academy of Sciences (CAS-TWAS) President Fellowship Programme for providing scholarship to pursue PhD.

Conflicts of Interest: The authors declare no conflict of interest. 


\section{Appendix A}

Table A1. The forecast of environmental indicators of the Baikal region.

\begin{tabular}{|c|c|c|c|c|c|c|c|c|c|c|c|c|c|c|}
\hline \multirow[b]{2}{*}{ No. } & \multirow[b]{2}{*}{ Indicator } & \multirow{2}{*}{$\begin{array}{c}\text { Actual } \\
2018\end{array}$} & \multicolumn{12}{|c|}{ Forecast } \\
\hline & & & $\begin{array}{c}\text { Estimate } \\
2019\end{array}$ & 2020 & 2021 & 2022 & 2023 & 2024 & 2025 & 2026 & 2027 & 2028 & 2029 & 2030 \\
\hline \multicolumn{15}{|c|}{ 1. Eco-capacity of air, $\mathrm{kg}$ per capita } \\
\hline 1.1 & Republic of Buryatia & 114.8 & 103.266 & 105.773 & 107.279 & 99.981 & 99.782 & 98.121 & 94.304 & 88.943 & 84.588 & 82.601 & 80.344 & 79.29 \\
\hline 1.2 & Irkutsk oblast & 275 & 273.001 & 268.539 & 252.598 & 250.283 & 248.225 & 242.606 & 235.311 & 225.313 & 216.675 & 210.944 & 195.986 & 179.825 \\
\hline 1.3 & Zabaykalsky krai & 125 & 114.85 & 110.849 & 112.693 & 115.668 & 114.694 & 112.067 & 110.833 & 100.299 & 98.951 & 95.771 & 93.5 & 90.339 \\
\hline \multicolumn{15}{|c|}{ 2. Eco-capacity of wastewater, $\mathrm{m}^{3}$ per capita } \\
\hline 2.2 & Irkutsk oblast & 343 & 320.196 & 286.403 & 275.095 & 276.641 & 264.926 & 256.71 & 251.545 & 252.476 & 249.293 & 250.665 & 251.951 & 248.533 \\
\hline 2.3 & Zabaykalsky krai & 199 & 185.247 & 172.138 & 168.198 & 160.243 & 158.869 & 151.164 & 154.851 & 153.269 & 151.346 & 152.648 & 150.997 & 147.584 \\
\hline \multicolumn{15}{|c|}{ 3. Eco-capacity of waste, $\mathrm{kg}$ per capita } \\
\hline 3.1 & Republic of Buryatia & 49.168 & 56.025 & 58.628 & 56.238 & 52.489 & 47.793 & 42.93 & 34.706 & 38.869 & 38.749 & 37.826 & 26.994 & 25.567 \\
\hline 3.2 & Irkutsk oblast & 56.577 & 58.346 & 58.322 & 58.434 & 56.855 & 52.986 & 50.792 & 47.84 & 43.541 & 43.365 & 40.248 & 30.699 & 23.87 \\
\hline 3.3 & Zabaykalsky krai & 179.042 & 184.607 & 185.221 & 177.447 & 170.931 & 165.273 & 164.618 & 160.631 & 156.785 & 150.971 & 143.048 & 141.47 & 130.895 \\
\hline
\end{tabular}


Table A2. Forecast of eco-intensity indicators of the Baikal region.

\begin{tabular}{|c|c|c|c|c|c|c|c|c|c|c|c|c|c|c|}
\hline \multirow[b]{2}{*}{ No. } & \multirow[b]{2}{*}{ Indicator } & \multirow{2}{*}{$\begin{array}{c}\text { Actual } \\
2018\end{array}$} & \multicolumn{12}{|c|}{ Forecast } \\
\hline & & & $\begin{array}{c}\text { Estimate } \\
2019\end{array}$ & 2020 & 2021 & 2022 & 2023 & 2024 & 2025 & 2026 & 2027 & 2028 & 2029 & 2030 \\
\hline \multicolumn{15}{|c|}{ 1. Eco-intensity of air, $\mathrm{kg} / \mathrm{USD}$} \\
\hline 1.1 & Republic of Buryatia & 0.0019 & 0.00181 & 0.00174 & 0.00173 & 0.0017 & 0.00168 & 0.00163 & 0.00166 & 0.00164 & 0.00161 & 0.00159 & 0.00153 & 0.00152 \\
\hline 1.2 & Irkutsk oblast & 0.0323 & 0.0328 & 0.0323 & 0.0321 & 0.0318 & 0.0301 & 0.0295 & 0.0294 & 0.0287 & 0.0282 & 0.02801 & 0.028 & 0.027 \\
\hline 1.3 & Zabaykalsky krai & 0.026 & 0.0278 & 0.0277 & 0.02716 & 0.02723 & 0.02714 & 0.02704 & 0.0267 & 0.0262 & 0.0257 & 0.0245 & 0.0239 & 0.0225 \\
\hline \multicolumn{15}{|c|}{ 2. Eco-intensity of wastewater, tons/USD } \\
\hline 2.2 & Irkutsk oblast & 0.0403 & 0.0399 & 0.0374 & 0.0355 & 0.0334 & 0.0308 & 0.0266 & 0.0239 & 0.0217 & 0.0198 & 0.01589 & 0.0136 & 0.0121 \\
\hline 2.3 & Zabaykalsky krai & 0.0413 & 0.0412 & 0.0411 & 0.0399 & 0.0392 & 0.0389 & 0.0381 & 0.0372 & 0.0347 & 0.0326 & 0.0291 & 0.0257 & 0.0243 \\
\hline \multicolumn{15}{|c|}{ 3. Eco-intensity of waste, $\mathrm{kg} / \mathrm{USD}$} \\
\hline 3.1 & Republic of Buryatia & 0.8299 & 0.5545 & 0.4962 & 0.4582 & 0.3929 & 0.3235 & 0.3069 & 0.272 & 0.2701 & 0.2298 & 0.2339 & 0.2232 & 0.2027 \\
\hline 3.2 & Irkutsk oblast & 6.6506 & 8.032 & 7.903 & 7.127 & 7.03 & 7.026 & 6.513 & 6.317 & 6.255 & 5.925 & 5.864 & 4.765 & 3.99 \\
\hline 3.3 & Zabaykalsky krai & 37.246 & 36.982 & 35.843 & 34.177 & 34.023 & 33.73 & 32.303 & 29.735 & 27.056 & 26.833 & 25.456 & 25.124 & 24.2099 \\
\hline
\end{tabular}




\section{References}

1. Cheng, H.; Dong, S.; Li, F.; Yang, Y.; Li, Y.; Li, Z. A circular economy system for breaking the development dilemma of 'ecological Fragility-Economic poverty' vicious circle: A CEEPS-SD analysis. J. Clean. Prod. 2019, 212, 381-392. [CrossRef]

2. Davies, A.R.; Mullin, S.J. Greening the economy: Interrogating sustainability innovations beyond the mainstream. J. Econ. Geogr. 2011, 11, 793-816. [CrossRef]

3. A Guidebook to the Green Economy Issue 2: Exploring Green Economy Principles. Available online: https://sustainabledevelopment. un.org/content/documents /743GE\%20Guidebook\%202\%20-\%20Principles_final.pdf (accessed on 10 October 2020).

4. Barbier, E.B.; Markandya, A. A New Blueprint for A Green Economy, 1st ed.; Routledge: London, UK, 2013; 216p. [CrossRef]

5. Pearce, D.; Markandya, A.; Barbier, E. Blueprint for A Green Economy; Earthscan: London, UK, 1989.

6. Bina, O.; La Camera, F. Promise and shortcomings of a green turn in recent policy responses to the 'double crisis'. Ecol. Econ. 2011, 70, 2308-2316. [CrossRef]

7. Georgeson, L.; Maslin, M.; Poessinouw, M. The global green economy: A review of concepts, definitions, measurement methodologies and their interactions. Geo Geogr. Environ. 2017, 4, e00036. [CrossRef]

8. D'Amato, D.; Droste, N.; Allen, B.; Kettunen, M.; Lähtinen, K.; Korhonen, J.; Toppinen, A. Green, circular, bio economy: A comparative analysis of sustainability avenues. J. Clean. Prod. 2017, 168, 716-734. [CrossRef]

9. Nahman, A.; Mahumani, B.; De Lange, W. Beyond GDP: Towards a Green Economy Index. Dev. S. Afr. 2016. [CrossRef]

10. Barbier, E.B. The green economy post Rio+20. Science 2012, 338, 887-888. [CrossRef]

11. UN. The Future We Want. The Outcome Document of the UN Conference on Sustainable Development; United Nations: New York, NY, USA, 2012; 66p.

12. United Nations. The 2030 Agenda for Sustainable Development. Available online: http://www.un.org/ga/search/view_doc. asp?symbol=A/RES/70/1\&Lang=E (accessed on 9 June 2020).

13. The Adoption of the Paris Agreement. In Proceedings of the Conference of the Parties on its Twenty-fist Session, Paris, France, 30 November-11 December 2015; The Framework Convention of the United Nations Framework Convention on Climate Change; UN: New York, NY, USA, 2015; 42p. (In Russian). Available online: www.unfccc.int/resource/docs/2015/cop21/rus/109r.pdf (accessed on 13 December 2020).

14. Gibbs, D.; O'Neill, K. Green Entrepreneurship: Building a Green Economy?_Evidence from the UK. In Social and Sustainable Enterprise: Changing the Nature of Business (Contemporary Issues in Entrepreneurship Research); Underwood, S., Blundel, R., Lyon, F., Schaefer, A., Eds.; Emerald Group Publishing Limited: Bingley, UK, 2012; Volume 3, pp. 75-96. [CrossRef]

15. Mcafee, K. Green economy and carbon markets for conservation and development: A critical view. Int. Environ. Agreem. 2015. [CrossRef]

16. Bell, K. 'Living Well' as a Path to Social, Ecological and Economic Sustainability. Urban. Plan. 2017, 2, 19-33. [CrossRef]

17. Barbier, E. Building the Green Economy. Can. Public Policy 2016, 42, S1-S9. [CrossRef]

18. United Nations Department of Economic and Social Affairs. Policy Integration in Government in Pursuit of the Sustainable Development Goals; United Nations Department of Economic and Social Affairs: New York, NY, USA, 2015.

19. Pahle, M.; Pachauri, S.; Steinbacher, K. Can the Green Economy deliver it all? Experiences of renewable energy policies with socio-economic objectives. Appl. Energy 2016, 179. [CrossRef]

20. Lyubimova, E.V. First steps of solar energy in Siberia. Interexpo Geo-Sib. 2018, 1, 198-205.

21. Lambert, R.J.; Silva, P.P. The challenges of determining the employment effects of renewable energy. Renew. Sustain. Energy Rev. 2012, 16, 4667-4674. [CrossRef]

22. Barbier, E. Is green growth relevant for poor economies? Resour. Energy Econ. 2016, 45, 178-191. [CrossRef]

23. Gomboev, B.; Badmaev, A. "Green economy" as one of the grounds for reaching the goals of sustainable development. Bull. Buryat Sci. Cent. Sb Ras 2017, 2, 109-116.

24. Yantranov, A.; Sangadieva, I. Potential of the transition of the Baikal region's economy to sustainable development based on the principles of a "green" economy. Econ. Syst. Manag. 2017, 3, 25.

25. Zomonova, E. Definition and principles of green economy. Azimuth Sci. Res. Econ. Adm. 2016, 5, 13-17.

26. Bilgaev, A.; Dong, S.; Li, F.; Hao, C.; Sadykova, E.; Mikheeva, A. Assessment of the Current Eco-Socio-Economic Situation of the Baikal Region (Russia) from the Perspective of the Green Economy Development. Sustainability 2020, 12, 3767. [CrossRef]

27. Bilgaeva, L.; Sadykova, E.; Ochirova, G.; Zhigdorzhiev, V. Neuroevolutionary forecasting of innovative development of the region with ecological aspect. In Proceedings of the International Workshop AMSA'2017, Krasnoyarsk, Russia, 18-22 September 2017; NSTU: Novosibirsk, Russia, 2017; pp. 49-57.

28. Bilgaeva, L.; Sadykova, E.; Filippov, V. Automatic Generation of Neural Network Topology to Forecast the International Integration Processes. In Proceedings of the International Multi-Conference on Industrial Engineering and Modern Technologies, Vladivostok, Russian, 6-9 October 2020; FarEastCon: Vladivostok, Russian, 2019. [CrossRef]

29. Toolokhonov, A.K. How to Develop the Russian Periphery or Some Lessons from China's Reforms. ECO 2008, 7, 2-15.

30. Bilgaeva, L.P.; Sadykova, E.T.S.; Filippov, V.A. Automatic Construction of Neural Network Topology Using Activation Function Mutation to Solve the Forecasting Problem. No. 2019663738, 22 November 2019. 
31. Strategy of Socio-Economic Development of the Republic of Buryatia. Available online: https://egov-buryatia.ru/minec/activities/ directions/strategicheskoe-upravlenie/strategicheskoe-planirovanie/strategiya-ser-rb (accessed on 13 November 2020).

32. On Approval of the Progress Report on the Implementation of the Action Plan for the Zabaykalsky Krai Socio-Economic Development Strategy Implementation for the Period up to 2030. Available online: https://75.ru/o-krae/ekonomika/strategii (accessed on 13 November 2020).

33. Draft Strategy for the Socio-Economic Development of Irkutsk Oblast until 2036. Available online: https://irkobl.ru/sites/ economy/socio-economic/project2036/ (accessed on 13 November 2020).

34. Box, G.E.; Jenkins, G.M.; Reinsel, G.C.; Ljuing, G.M. Time Series Analysis: Forecasting and Control, 5th ed.; Wiley: Hoboken NJ, USA, 2016.

35. Guerard, J.B. Regression Analysis and Forecasting Models. In Introduction to Financial Forecasting in Investment Analysis; Springer: New York, NY, USA, 2013; pp. 19-45.

36. Gladkov, L.A.; Kureychik, V.V.; Kureychik, V.M. Genetic Algorithms; Fizmatlit: Moscow, Russia, 2006; 320p.

37. Aggarval, C.C. Data Mining; Springer: Cham, Switzerland, 2015.

38. Osovsky, S. Neural Networks for Information Processing; Hot Line-Telecom: Moscow, Russia, 2016; 448p.

39. Rosenblatt, F. Principles of Neurodynamics: Perceptrons and the Theory of Brain Mechanisms; Spartan Books: Washington, DC, USA, $1962 ; 616 \mathrm{p}$.

40. Eiben, A.E.; Smith, J.E. Introduction to Evolutionary Computing, 2nd ed.; Springer: Heidelberg/Berlin, Germany, 2015.

41. Cook, T.R.; Hall, A.S. Macroeconomic Indicator Forecasting with Deep Neural Networks. In Proceedings of the CARMA 2018 -2nd International Conference on Advanced Research Methods and Analytics, Valencia, Spain, 12-13 July 2018. [CrossRef]

42. Haykin, S. Neural Networks, A Comprehensive Foundation; Macmillan College Publishing Company: New York, NY, USA, 1994.

43. Osowski, S. Sieci Neuronowe w Ujecin Algorytmicznum; WNT: Warsaw, Poland, 1996.

44. Stanley, K.O.; Miikkulainen, R. Evolving Neural Networks Through Augmenting Topologies. Evol. Comput. 2002, 10, 109-127. [CrossRef]

45. Gorban, A.N. Training of Neural Networks; ParaGraph: Moscow, Russia, 1990; 160p.

46. Munshi, A.; Gaster, B.; Mattson, T.G.; Fung, J.; Ginsburg, D. OpenCL Programming Guide; Addison-Wesley Professional: Boston, MA, USA, 2011; 648p.

47. Rosstat. Regions of Russia. Socio-Economic Indicators; Rosstat: Moscow, Russia, 2018; p. 1162.

48. Federal State Statistic Service Republic of Buryatia Branch. Available online: https:/ /burstat.gks.ru/publication_bur (accessed on 19 June 2020).

49. Federal State Statistic Service Irkutsk Oblast Branch. Available online: https://irkutskstat.gks.ru/folder/35281 (accessed on 19 June 2020).

50. Federal State Statistic Service Zabaykalsky Krai Branch. Available online: https://chita.gks.ru/publication_collection (accessed on 19 June 2020).

51. State Program of the Russian Federation "Social Support of Citizens". Available online: https://mintrud.gov.ru/ministry/ programms/3/2/ (accessed on 9 November 2020).

52. State Program of the Russian Federation "Socio-Economic Development of the Far Eastern Federal District". Available online: https:/ / minvr.gov.ru/activity/gosprogrammy/sotsialno-ekonomicheskoe-razvitie-dalnevostochnogo/ (accessed on 9 November 2020).

53. The Strategy of Socio-Economic Development of the Russian Federation until 2035. Available online: https://www.economy.gov. ru (accessed on 10 November 2020).

54. Lin, M.-X.; Liou, H.M.; Chou, K.T. National Energy Transition Framework toward SDG7 with Legal Reforms and Policy Bundles: The Case of Taiwan and Its Comparison with Japan. Energies 2020, 13, 1387. [CrossRef]

55. The Strategies for the Spatial Development of the Russian Federation for the Period up to 2025. Available online: http: / / static.government.ru/media/files/UVAlqUtT08060RktoOX122JjAe7irNxc.pdf (accessed on 10 November 2020).

56. O'Neill, K.; Gibbs, D. Rethinking green entrepreneurship-Fluid narratives of the green economy. Environ. Plan. A 2016, 48. [CrossRef]

57. Tsoutsos, T.; Frantzeskaki, N.; Gekas, V. Environmental impacts from the solar energy technologies. Energy Policy 2005, 33, 289-296. [CrossRef]

58. Turney, D.; Fthenakis, V. Environmental impacts from the installation and operation of large-scale solar power plants. Renew. Sustain. Eneregy Rev. 2011, 15, 3261-3270. [CrossRef]

59. Gasparatos, A.; Doll, C.; Esteban, M.; Ahmed, A.; Olang, T. Renewable energy and biodiversity: Implications for transitioning to a Green Economy. Renew. Sust. Energ. Rev. 2017, 70, 161-184. [CrossRef]

60. Molina-Moreno, V.; Núñez-Cacho Utrilla, P.; Cortés-García, F.J.; Peña-García, A. The Use of Led Technology and Biomass to Power Public Lighting in a Local Context: The Case of Baeza (Spain). Energies 2018, 11, 1783. [CrossRef]

61. Han, X.; Zhang, M.; Liu, S. Research on the relationship of economic growth and environmental pollution in Shandong province based on environmental Kuznets curve. Energy Procedia 2011, 5, 508-512. [CrossRef] 
62. Scotini, R.; Skinner, I.; Racioppi, F.; Fusé, V.; Bertucci, J.D.O.; Tsutsumi, R. Supporting Active Mobility and Green Jobs through the Promotion of Cycling. Int. J. Env. Res. Public Health 2017, 14, 1603. [CrossRef]

63. Khovavko, I.Y. On the Problems of the Baikal Region in the Context of Modern Russian Environmental Policy. Public Adm. 2018, 69, 358-380. [CrossRef]

64. Vasiev, M.; Bi, K.; Denisov, A.; Bocharnikov, V.; Feng, L. How Coronavirus Pandemics (COVID-19) Influences Chinese Economic Sustainability. Foresight STI Gov. 2020, 14, 7-22. [CrossRef] 